Van de Walle, S. \& Brans, M. (2018, accepted). Where comparative public administration and comparative policy studies meet. Journal of Comparative Policy Analysis.

\title{
WHERE COMPARATIVE PUBLIC ADMINISTRATION AND COMPARATIVE POLICY STUDIES MEET
}

Version 14 Nov 2017

Steven Van de Walle \& Marleen Brans

KU Leuven, Public Governance Institute 


\title{
WHERE COMPARATIVE PUBLIC ADMINISTRATION AND COMPARATIVE POLICY STUDIES MEET
}

\begin{abstract}
Comparative public administration studies the capacity of government and public actors to design and implement policies. This article in the JCPA anniversary issue discusses similarities and differences between comparative public administration and comparative public policy. It does so using the concept of policy capacity, a capacity that is supplied by public actors and institutions. We show where comparative public policy and comparative public administration meet in different stages of the policy cycle and where they have built their own distinctive but complementary bodies of knowledge.
\end{abstract}

Keywords:

Comparative public administration, policy capacity, policy implementation 


\section{WHERE COMPARATIVE PUBLIC ADMINISTRATION AND COMPARATIVE POLICY STUDIES MEET}

\section{Introduction}

Policies needs bureaucrats and bureaucracies to make and design policies and to implement policies. Public administrations provide policy capacity to public administration and are the machinery of government. While the realm of policy has moved ways from state-centric approaches to policy-making, bureaucratic structures and personnel remain essential in the policy process. In this article, we will sketch the main developments in comparative public administration and show where and how comparative public administration and comparative policy meet around the concept of policy capacity.

In this contribution, the term Comparative Public Policy Studies (CPP) is deployed as an umbrella term for denoting different strands of academic approaches for comparatively understanding 'what governments do, why they do it and what difference does it make (Dye, 1976)'. Comparative Public Administration (CPA) has a focus on how governments do it, and with what resources, also in a comparative perspective.

The absence of a dominant paradigm for delineating the field of public policy studies extends to the comparative realm. There are many kinds of comparative policy studies seeking an understanding of the nature of policy choices and their causes and consequences. Adding to the heterogeneity in comparative policy analyses is the still pervasive double claim of two of the founding fathers of modern policy analysis (Lasswell and Lerner, 1951): the need for scientifically sound research and the call for bringing knowledge to use for providing policy advice. On the one hand, comparative public policy studies are expected to be guided by scientific standards of inference regarding similarities and differences of policies and their making in different contexts. On the other hand, comparative knowledge of what works under which conditions provides opportunities for lesson-drawing and policy transfer on real-life manipulable policies and processes. To be sure, the application orientation is stronger in analyses performed by a broad range of actors including government agencies, but also interest-groups, international organizations, think tanks and foundations. The extent to which lesson-drawing and policy transfer is aspired by academic policy research will depend on disciplinary boundaries and incentive structures for impact or on the policy entrepreneurship of individual academics (Blum and Brans, 2017).

There is a lot to be said about the meeting points of comparative public administration with applied policy lesson-drawing and transfer. It should be acknowledged that the diffusion of rational planning systems in the 1960s and 1970s, notably of PPBS, drew CPA and CPP in the 
same bath, and in many countries outside the US, the disciplines only started drifting apart when the questioning of rationality and technocracy went hand in hand with the growth of policy process studies (Brans and Blum 2017). Meanwhile substantive policy analysis developed as another strand of comparative policy research with variable autonomy from policy process studies and CPA. Comparative research on welfare policies, education and from the end of the last century increasingly also environmental policies have focused on the nature of problems, content of solutions, and their effects and impacts. Apart from implementation research in the domain of social work and the emerging attention for policy instrumentation comparative substantive policy research has traditionally shied away from the nuts and bolts of the public administration. Coupled with CPA's relative disinterestedness in substantive issues, the meetings points between CPA and substantive policy research have traditionally been scarce.

Even though CPA can speak to both applied and substantive comparative policy analysis, the remainder of this contribution limits its discussion to the encounters between CPA and CPP process studies. It will first briefly touch on the history of CPA and CPP. It will then show how the fields meet in the policy cycle to next discuss how CPA is crucial for researching various dimensions of the policy capacity that is needed to formulate, implement, and evaluate policies. Subsequently we sketch the development and current organisational state of the field and its main players. Then, current data and methodological challenges in CPA are discussed. The article ends by discussing a number of challenges for the field.

\section{Comparing administrations, comparing policies: A common history?}

While apparently close, CPA and CPP only share part of their history. Whereas CPA finds its origins with academic public administration scholars who started studying developing countries, the history of CPP can more closely be related to developments within government. Public policy, and its ancestor, policy science, share an applied problem-oriented approach, often with a strong value orientation and relying on multidisciplinary approaches (DeLeon, 2006). Much of it emerged within analytic units inside government with an explicit aim to solve problems related to issues such as defense, poverty or health.

CPA, by contrast, does not have a similarly strong problem-solving orientation. The roots of what is now commonly called Comparative Public Administration can be traced back to what used to be called 'Development Administration' (Siffin, 1991: 7). Funded by foundations such as the Ford Foundation with an ambition to support decolonization processes, the early scholars of CPA struggled with a tension between the Foundation's practical objectives and their own attempts to give public administration more theoretical groundings. In fact, development administration offered them a path away for the very strong practical orientation 
of the American public administration community (Subramaniam, 2000; Riggs, 1997). The early CPA had an ambition to build and test theory for the sake of it, without strong ties to daily policy needs of governments or research sponsors.

With the end of the main wave of decolonization attention for CPA also withered. The rise of the NPM spared renewed interest in explicit comparison, mostly with a focus on the AngloSaxon countries (Otenyo \& Lind, 2006: xxxv). Increasing data availability through academic data-collection and through the emergence of cross-country datasets created by OECD and the World Bank further stimulated comparative research. More recently, funding from e.g. the European Union or the Inter-American Development Bank further stimulated comparative work focusing on specific regional entities. CPA has been growing during the last decade (Jreisat, 2005; Pollitt, 2011, Brans 2012), and introducing comparative elements in what would earlier have been purely local designs has become commonplace. Still, CPA is not mainstream, as demonstrated by an analysis of Raadschelders and Lee (2011) showing that a mere $13.6 \%$ of articles in Public Administration Review had an explicit comparative perspective. It is telling that comparative, in this analysis, meant the article contained a comparison to the US, or concerned foreign countries.

\section{Where CPA and CPP meet in the policy cycle}

In his classic 1887 article 'The Study of Administration' Woodrow Wilson stated that 'Without comparative studies in government we cannot rid ourselves of the misconception that administration stands upon an essentially different basis in a democratic state from that on which it stands in a non-democratic state.' (1887: 218). Comparative Public Administration studies the machinery inside government. Whereas comparative public policy is concerned with the comparison of policies and with the comparative study of the policy process (Gupta, 2012), CPA mainly looks at the role of public officials and the administrative apparatus. Unlike CPP, CPA less interested in substantive aspects of policies or processes of policy, whereas for CPP scholars this is an integral part of their research.

\section{CPA in the policy cycle}

One of the classic exports from US policy analysis to emerging policy studies in the after-war period was the policy cycle and the stages it was broken in to. Although the literature is rife with different names and numbers of stages, the basic idea is that the policy-making process can be described by dividing it up in agenda-setting, policy formulation, decision-making or legitimation, implementation, evaluation -and to close the cycle- policy feedback under different forms, such as termination, succession or change. The policy cycle model has been criticized for being an untruthful linear representation of the policy process and for its 
inability to explain what it describes (Jann and Wegrich, 2007). It is contested by a number of models that are very much at the heart of developments in policy process studies, such as the Advocacy Coalition model or the multiple streams model. Yet, the cycle model remains useful as a heuristic tool to describe how policy problems are marked for government action, what the actors and dynamics are of goal setting and solution finding, who takes legitimate policy decisions, how policies are maintained or changed by processes of implementation, who observes and judges their outputs and outcomes, and what constitutes policy status quo, change or termination. It also helps, as Howlett et al. (2009) show, to disentangle the actors, institutions and ideas that respectively create agency, engender opportunities or constraints, and provide content.

The heuristic quality of the model also serves to highlight meeting points of CPA and CPP. Typically, CPA appears in the policy cycles in those stages where government actors and institutions are, even when not the sole, then at least central actors with legitimate mandates to support the making of policies. Traditionally, agenda-setting has not attracted much academic interest from the CPA community, with the exception perhaps of scholarship on the roles of international organizations and actors in the diffusion and imposition of public sector reform and the international spread of management and governance models (Pal, 2012).

Policy formulation is a more vibrant hub for CPA knowledge to bear upon CPP. The policy work performed by bureaucrats is a classic subject of attention in the study of bureaucracy (Meltsner, 1976; Page and Jenkins, 2005), and in comparative studies of relationship between politicians and bureaucrats (Van der Meer et al., 2013). The original focus on bureaupolicy advisors (policy advisors internal to government), has meanwhile been shifted by the trend to the externalization of policy advice (Craft and Halligan, 2017). Comparative studies of policy work now embrace the involvement of many external actors in policy formulation, and the engagement of stakeholders in policy design is captured under studies of co-creation and codesign.

Decision-making is commonly seen as the most political stage of the policy cycle and its key actors have been favorite units of analysis of political science and policy studies alike, and less so of public administration scholarship. Yet, here pops up a missing link in the policy cycle, one that bureaucrats can forge. Policy choices do not simply travel from the politically mandated decisions to sets of rules and programs ready for execution. Recent comparative work on policy-making without politicians has revealed the discretionary power of bureaucrats in secondary legislation and their power to determine the content of policy choices (Page, 2012). 
The implementation stage of the policy cycle is the traditional playing field of government agencies and their partners in governance. Implementation connects CPP with a number of classic concerns of CPA: the tension between specialization and co-ordination (Verhoest and Bouckaert, 2005), issues of control and compliance, the tools of government (Hood, 1986), policy instruments and regulatory traditions. Also the discretion of street-level bureaucrats and their power over the reach and quality of service delivery is a steady subject of study (Hill and Hupe, 2008). The machinery of government, the nature of policy instruments and realities at the delivery end have become important variables for explaining policy outputs in many policy domains. Evaluation as a subject of study is closely associated with applied policy analysis. Yet, it has also drawn the attention of public administration scholars interested in evaluation capacity building, and the institutionalization of a culture of evaluation (Pattyn, 2014). Worth mentioning are also comparative performance management studies and the comparative critique of performance indicators (Van Dooren, Bouckaert and Halligan, 2014; Pollitt, 2005). Policy feedback, change and termination are less of a domain where CPA is active, except for public sector reform studies and comparative studies on the consequences of the global financial crisis of the late 2000s (Kickert, Randma-Liiv and Savi, 2015).

\section{Policy capacity and CPA}

CPA has variable encounters with CPP in different stages in the policy cycle. A different and perhaps more structured way of mapping where CPA brings useful knowledge to the study of policy-making is by relating it to various dimensions of policy capacity, needed for the formulation, implementation and evaluation of policies. The matrix model of $\mathrm{Wu}$, Ramesh and Howlett (2017) is an enlightening scheme for disentangling various dimensions of policy capacity. For the authors, policy capacity is in essence a function of three competences or skills that constitute the ability of governments to make, implement and evaluate policies, as well as to learn and adapt. The three competences rely on the mobilization of resources at the individual, organizational, and system level. The authors distinguish between analytical, operational (or managerial) and political skills and competences. Analytical skills are deployed for problem diagnostics, solution finding, and policy evaluation. Operational skills mobilize material and organizational resources to implement policies in practice. Political skills enable policy actors to mobilize resources for garnering and maintaining support for policies and their implementation (Wu et al. 2017: 5). To these three set of competences, we add legal competences as a fourth category to redress the relative neglect of lawmaking skills, legal procedures and adjudication in policy capacity studies. Legal competences are necessary 
to transpose policies in law and regulations, ensure due process, enforce compliance and control, and protect citizens from policies' harm. 
Table 1: Dimensions of policy capacity and CPA research

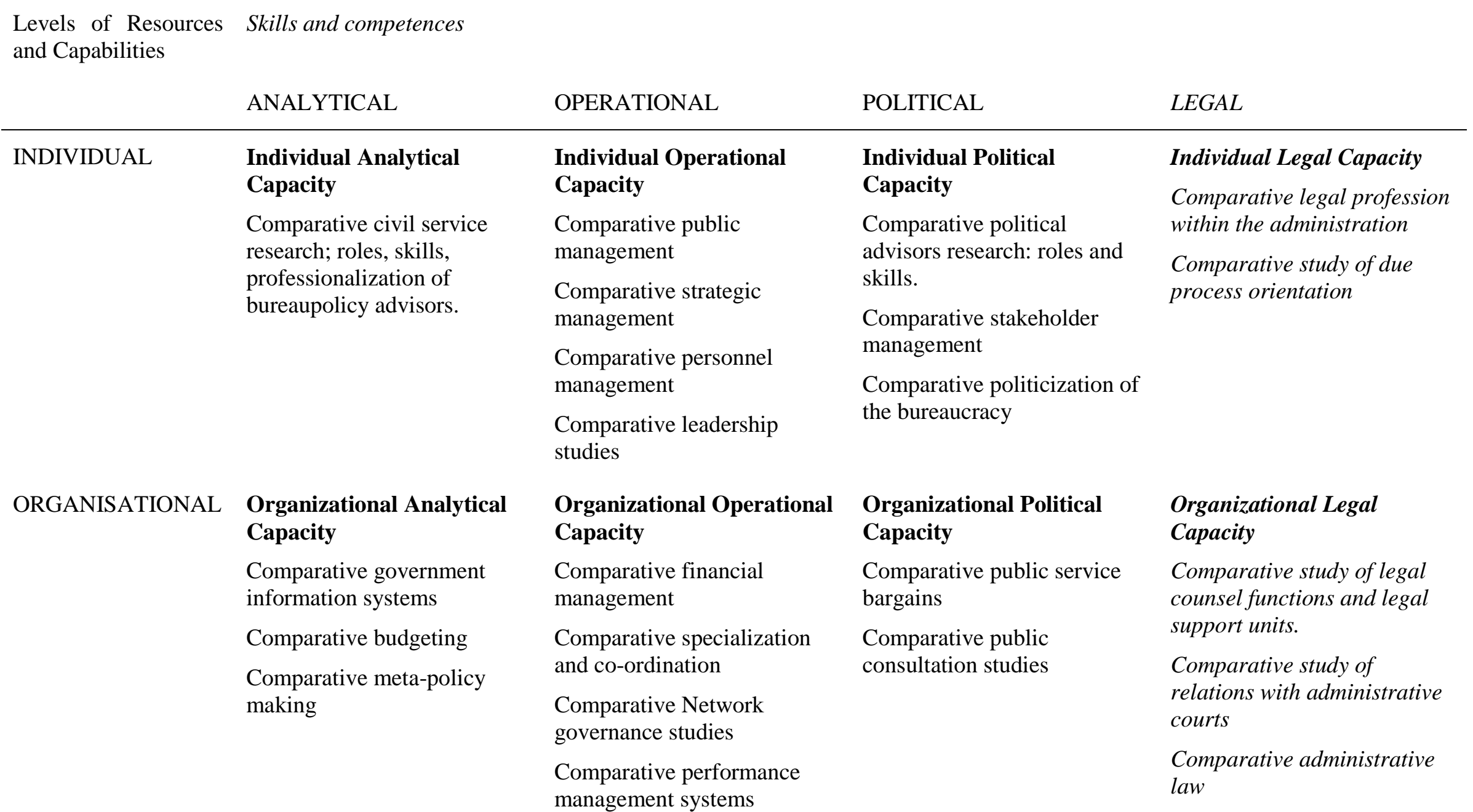




\begin{tabular}{|c|c|c|c|c|}
\hline SYSTEM & $\begin{array}{l}\text { Systemic Analytical } \\
\text { Capacity } \\
\text { Comparative PA education } \\
\text { and training } \\
\text { Comparative advisory } \\
\text { systems }\end{array}$ & $\begin{array}{l}\text { Systemic Operational } \\
\text { Capacity } \\
\text { Comparative accountability } \\
\text { studies }\end{array}$ & $\begin{array}{l}\text { Systemic Political Capacity } \\
\text { Comparative trust in } \\
\text { government studies } \\
\text { Comparative transparency } \\
\text { Comparative participation } \\
\text { studies } \\
\text { Comparative public finance }\end{array}$ & $\begin{array}{l}\text { Systemic Legal Capacity } \\
\text { Comparative regulatory } \\
\text { impact studies } \\
\text { Comparative regulatory } \\
\text { quality studies } \\
\text { Comparative administrative } \\
\text { burden studies. }\end{array}$ \\
\hline
\end{tabular}

Source: Wu et al. (2017: 5). Column on legal capacity added by the authors. Boxes in italic added by the authors. 
In each of the 12 boxes, CPA produces useful knowledge for comparatively understanding resource mobilization for the four sets of competences that constitute governments' policy capacity. Because of its prime focus on the government apparatus and its personnel, CPA is relatively more active in analyzing these competences at the individual and organizational level. Yet, also at the systemic level CPA has knowledge on offer.

At the individual level, comparative civil service research (Aberbach et al., 1981; Page and Wright 1999) and political advisors research (Hustedt et al., 2017) delves into the roles and skills of 'bureaupolicy, bureaupolitical and political advisors (Brans 2018 forthcoming)' in government and in their garnering of political and societal support for policies. The multiple foci of comparative public management studies, including leadership studies (Van Wart et al., 2014), are useful for understanding the roles and skills of managers of all kinds. Lawyers in government are more scarcely addressed, particularly when it comes to their contributions to policy-making. Available research, however, shows how important legal skills and bureaucratic discretion are in bill writing and the transposition of policy intentions in regulations (Page, 2012).

Next to the study of analytical, managerial, political, and legal personnel of government, organizational capacity of government agencies lies at the heart of comparative public administration. Organizational analytical capacity is addressed in comparative studies of government information systems, e-government and communication, budgeting, consultation, and meta-policy-making. Comparative operational capacity at the organization level is informed by CPA scholarship on the tensions between specialization and co-ordination, network governance, and performance management systems, to name but a few foci. Organizational political capacity in turn has mainly been approached from the comparative study of public service bargains between politicians and bureaucrats (Hood and Lodge, 2006). While important subjects for the study of organizational legal capacity, research on the role of legal counsel functions, legislative drafters, and legal support units in government is emergent in public administration scholarship (Mastenbroek, 2017).

As mentioned above, systemic analytical capacity is not the prime focus of CPA research. Yet a comparative understanding thereof would do well to turn to studies that describe and explain the nature of PA training in higher education programs (Pal and Clark, 2016) or the presence of evidence-friendly advisory systems. Systemic operational capacity in turn can be informed by studies of managerial accountability. Studies on trust, transparency, and participation align with questions on systemic political capacity. Finally, a comparative understanding of systemic legal capacity can be aided by research on regulatory quality, impacts and burdens (Levi-Faur, 2011). 


\section{Who are the players?}

CPA and CPP share research interest but tend to focus on different stages of the policy cycle and CPA contributes to the study of specific dimensions of policy capacity. Both (sub)disciplines have much in common as a research community, but scholars also to some extent live within their own scholarly communities, even when working within the same departments.

\section{Departments and conferences}

CPA and CPP scholars often share academic departments. This is for instance the case for the Dutch or the German scholars who tend to reside in public administration or political science departments. Schools of Government and Schools of Governance are also places where the two communities meet. Sometimes, both groups reside in their own departments. This is especially the case where Policy Schools are important features of the academic landscape (Brans and Blum 2017). In addition, specialized groups of CPA scholars can be found in development studies departments or health management groups; whereas specialized groups of CPP scholars can be traced within organizational units tasked with studying one or several substantive policy areas. International organizations such as OECD and the World Bank and international NGOs and foundations such as the Bertelsmann Foundation are also increasingly active in the fields of CPA and CPP.

CPA and CPP scholars meet at conferences such as ECPR, EGPA or ASPA, but also increasingly have their own fora to exchange ideas. For CPP scholars, APPAM and ICCP are more natural fora, whereas CPA scholars tend to attend conferences such as PMRC and IRSPM. The two communities are not mutually exclusive as one tends to see CPA scholars at CPP meetings and vice versa. This is for instance the case at the bi-annual ICPP conference, where in 2015 nearly 50 percent declared a disciplinary affiliation to public administration governance and management, and at the EGPA conference, whose 22 study groups count 2 groups on policy research. Yet, an increasing specialization in the discipline makes both groups have increasing opportunities to meet at specialized fora or in specialized silos at general conferences.

\section{Journals and disciplines}

While most Public Administration scholarship is not internationally comparative, comparativists tend to publish in journals such as Public Administration, the International Review of Administrative Science and Public Administration Review. Also journals such as Public Management Review and the Journal of Public Administration Research and Theory occasionally publish comparative work. Only few journals position themselves at the 
intersection of policy and administration scholarship, with Governance, the Journal of Public Analysis and Management and perhaps Public Administration as exceptions. Public policy, public administration and public management scholars share a single Web of Science category, but mostly withdraw in their own journals. In a survey of close to 300 European core public administration scholars, just two reported having published in policy Sciences, 3 in JPAM, and 9 in the Policy Studies Journal (Curry et al., 2014).

Just like policy scholars, public administration scholars remain firmly rooted in political science as a discipline, but one can also observe a string tendency for public administration to stand on its own feet as a discipline. In a survey of European Public Administration scholars in 2013 it was found that most obtained their highest degree in political science and public administration. Just under a quarter has a background in management of public management. This again demonstrates the importance of the internal machinery of government in the study of public administration. The same survey also asked these European PA scholars to indicate how important other disciplines are to their work, on a scale ranging from 1 being not at all important to 7 being extremely important. Political science is seen as the most important affiliated discipline, followed by sociology and business/management.

\section{Figure 1: Disciplinary background of European PA scholars}

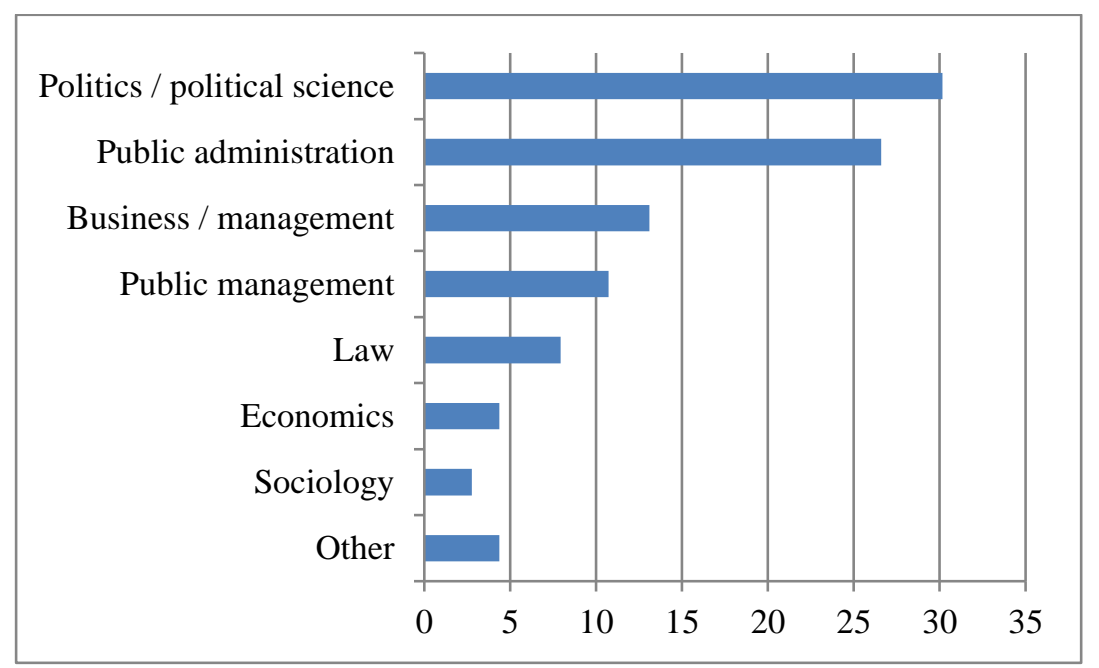


Figure 2: Importance of disciplines to PA scholars

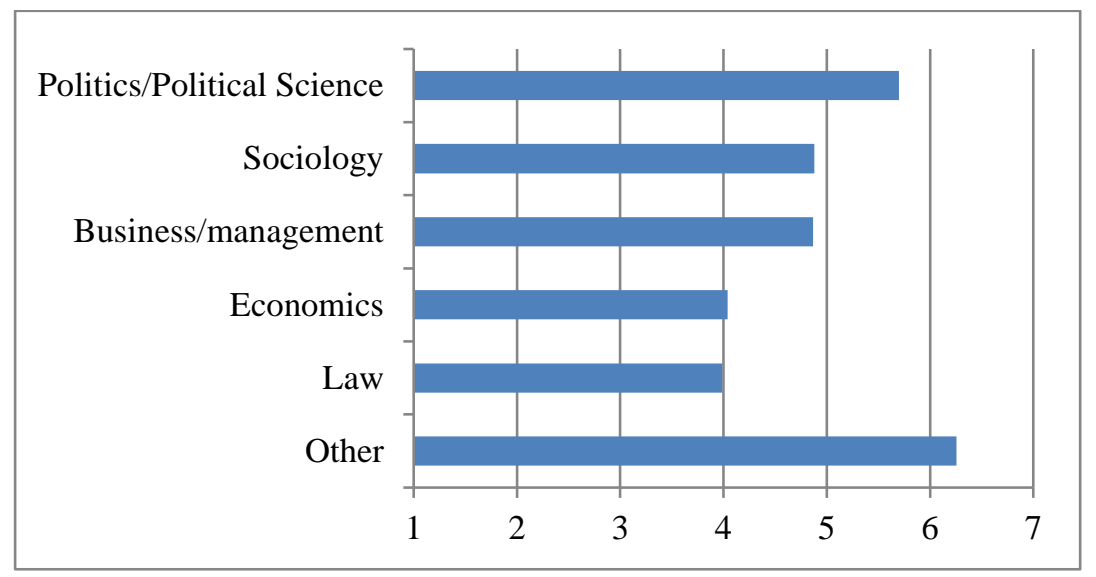

Note: Figure taken from Curry et al., 2014. $\mathrm{N}$ in this graph ranges between 266 and 273 depending on the question.

\section{Data and methods}

\section{A slow development of comparative datasets}

Unlike disciplines such as international economics or political science, the discipline of CPA cannot benefit from an abundant availability of established authoritative datasets. Material used in comparisons is either based on stand-alone academic data collection, or on datasets compiled by international organizations and NGOs. It is telling that one of the man data sources to study OECD countries, OECD's Government at a Glance was just published for the first time in 2009. The World Bank Worldwide Governance Indicators are older, but also data back to just 1996. As we have argued earlier in this journal, such datasets are necessary for the work of comparative scholars, yet they continue to suffer from validity and reliability issues (Van de Walle, 2006, Brans and Pattyn 2017). In recent years, scholars have stepped up their efforts to collect their own data (Verhoest et al., 2017). Examples of such datasets are the COBRA survey on agencies (Verhoest et al., 2016., the COCOPS Top Public Executive Survey (Hammerschmid et al., 2016), or various datasets by the Quality of Government Institute (Teorell et al., 2017) also come to mind.

Fitzpatrick et al.'s (2001) study on developments in CPA showed that three quarters of comparative articles use existing datasets, be it statistical data, secondary research data or official documents. This clearly demonstrates a transformation in the field away from a more essayistic and normative public scholarship.

Better data is necessary for the further development of CPA, without however falling in the trap of looking at too many variables in a too limited set of countries (Wilson, 2011). Scholars should also avoid moving to raw large-N empiricism devoid of theory (Subramaniam, 2000; 
Raadschelders, 2011), or ending up in a situation where developments in countries are described where scholars cannot even locate those countries on a map.

\section{Collecting, not comparing}

In a 2011 review of trends in 10 years of comparative research, Fitzpatrick et al. looked at papers published in 28 journals, and found that almost half of these are purely descriptive. This is in line with findings reported back in the 1970s that concluded that almost half of the scholarly work in CPA consisted of mere essays (Sigelman, 1976). The pattern is repeated in the 1980s where CPA scholarship remains dominated by descriptive work and thesis assertion. A mere 12 per cent of articles published in the 1980s had theory-testing ambitions. (Van Wart \& Cayer, 1990). More recently, Pollitt (2011) argued that much of the CPA scholarship lacks theory.

Comparative Public Administration suggests comparison is the purpose of the study. Yet, what we see is often a collection of data in different systems, and replication of research across different systems, without explicit comparison involved. Many studies are based on convenience samples of countries that have little theoretical reason to be together in the same analysis. Mostly Western countries are compared (Guljarani and Moloney, 2012) and comparison mainly concern just two or three countries (Fitzpatrick et al., 2011).

When reading the average CPA course syllabus one cannot help noticing that CPA is not so much about comparing countries and systems, but about studying other countries' systems, often even without explicit comparisons being made. In the US tradition, Comparative Public Administration stands for 'the study of foreign administrative institutions and practices' (Henderson, 1969), and little explicit comparison is made. When looking at the handbooks, a similar phenomenon emerges. Rather than consisting of comparative chapters on selected topics, they mostly consist of a series of country chapters (Farazmand, 1991; Chandler, 2000; Pierre, 1995). A particular exception is Kuhlmann and Wollmann's Introduction to Comparative Public Administration (2014) even though it is mainly focusing on Europe.

\section{Challenges and developments in the field of CPA}

We started this article asserting that CPP and CPA have a different focus; the former has a focus on substantive policies and on policy processes, whereas the latter focuses on policy capacity. Still, there is substantial overlap between the two groups, not only in substance, but also in terms of methods, people and fora. In a sense, the distinction put forward is artificial. Trends in policy and administration make that the distinction between the machinery of government and governance and the processes and substance of policy increasingly overlap. This is in particular visible in the evolution towards networked governance in policy making 
and policy implementation. Government and its administrative machinery remains a fundamental actor in policy, but increasingly has to share its space with other actors who cocreate policies and co-produce public services. Policy capacity then, resides among multiple actors.

New players increasingly assert their place, yet do not necessarily join the community. Whereas CPA and CPP have traditionally been a relatively small subdiscipline consisting mainly of political scientists, one can observe increasing interest for its topics. Economists have already for a long time rediscovered institutions (North, 1990), and the randomistas in development studies increasingly focus on public service delivery (Banerjee \& Duflo, 2011). Economists have for a long time studied substantive policy areas yet without strong links to CPA or CPP scholars. Psychologists have started to take note of public administration following the rising popularity of nudging. International organizations and non-profits appear to be showing an increasing interest for the policy capacity of government. An important challenge for the disciplines of CPA an CPP will be to make sure these groups also feel at home and fully participate in the scholarly community rather than retreat within their own subdiscipline.

\section{References}

Aberbach, J.D., Putnam, R.D. and B.A. Rockman (1981) Bureaucrats and Politicians in Western Democracies. Cambridge, Harvard University Press.

Banerjee, A. V., \& Duflo, E. (2011). Poor economics: A radical rethinking of the way to fight global poverty. Public Affairs.

Brans, M. (2012) Comparative Public Administration: From General Theory to General Frameworks, in Peters, B.G. and Pierre, J. (2012) The Sage Handbook of Public Administration, London, Sage: 424-438.

Brans, M. (2018 forthcoming) Policy Advice and Public Policy. In: Thompson, B. (Eds.) Oxford Research Encyclopedia of Politics, Oxford, Oxford University Press.

Brans, M. and Vancoppenolle, D. (2005) Policy-making reforms and civil service systems : an exploration of agendas and consequences. In: Painter, M. and Pierre (Eds) Challenges to state policy capacity : global trends and comparative perspectives. Basingstoke, Palgrave Macmillan: 164-184. 
Brans, M. and Blum, S. (2017) Public Administration and Public Policy. Presentation for the workshop ‘The Many Disciplines of Public Administration', European Perspectives for Public Administration, Potsdam, 14 and 15 September 2017.

Brans, M. and Pattyn, V. (2017) Validating Methods for Comparing Public Policy: Perspectives from Academics and "Pracademics". Introduction to the Special Issue, Journal of Comparative Policy Analysis, 19(2017)4: 303-312

Blum, S. and Brans, M. (2017) 'Academic policy analysis and research utilization for policymaking', In Brans, M, Geva-May, I. and Howlett, M. (eds.): The Routledge Handbook of Comparative Policy Analysis. London: Routledge: 341-359.

Chandler, J.A. (2000). Comparative Public Administration. London: Routledge

Curry, D. Van de Walle, S. \& Gadellaa, S. (2014). Public Administration as an academic disicpline: Trends and changes in the COCOPS academic survey of European Public Administration scholars. Rotterdam: Erasmus University Rotterdam.

DeLeon, P. (2006). The historical roots of the field. The Oxford handbook of public policy, 39-57. Oxford: Oxford University Press.

Dye, T.S. (1976) Policy Analysis: What Governments Do, Why They Do It And What Difference It Makes. Tuscaloosa: University of Alabama Press.

Farazmand, A. (1991). Handbook of Comparative and Development Public Administration. New York: Marcel Dekker, Inc.

Fitzpatrick, J., Goggin, M., Heikkila, T., Klingner, D., Machado, J. \& Martell, C. (2011). A New Look at Comparative Public Administration: Trends in Research and an Agenda for the Future. Public Administration Review, 71(6): 821-830.

Guljarani, N., and Moloney, K. (2012). Globalizing Public Administration: Today’s Research and Tomorrow's Agenda. Public Administration Review, 72(1): 78-86.

Gupta, K. (2012). Comparative public policy: Using the comparative method to advance our understanding of the policy process. Policy Studies Journal, 40(s1), 11-26.

Hammerschmid, G., Van de Walle, S., Andrews, R., \& Bezes, P. (eds)(2016) Public administration reforms in Europe. The view from the top. Cheltenham: Edward Elgar.

Henderson, K.M. (1969). Comparative Public Administration: The Identity Crisis. Administration \& Society, 1(1): 65-84.

Hill, M., \& Hupe, P. (2008). Implementing public policy: An introduction to the study of operational governance. London: Sage. 
Hood, C. (1986). The tools of government. Chatham. NJ: Chatham House.

Hood, C. and Lodge, M. (2006) The Politics of Public Service Bargains: Reward, Competency, Loyalty - and Blame. Oxford, Oxford University Press.

Howlett, M., Ramesh, M. and Perl, A. (2009) Studying public policy, policy cycles and policy subsystems (3rd edn), Toronto: Oxford University Press.

Hustedt, T, Kollveit, C. and Houlberg Salomonsen, H. (2017) 'Ministerial advisors in the executive: out from the dark and into the limelight.', Public Administration, 95(2): 299-311.

Jann, W. \& Wegrich, K. (2007). Theories of the policy cycle. In: Fischer, F., Miller, G. J., \& Sidney; M. S. (eds). Handbook of public policy analysis: Theory, politics and methods, 43-62. Boca Raton: CRC press.

Jreisat, J.E. (2005). Comparative Public Administration Is Back In, Prudently. Comparative Public Administration, 65(2): 231-242.

Kuhlmann, S., \& Wollmann, H. (2014). Introduction to comparative public administration: Administrative systems and reforms in Europe. Edward Elgar Publishing.

Lasswell, H.D. (1951) 'The policy orientation.' In H.D. Lasswell \& D. Lerner (eds.): The Policy Sciences. Recent Developments in Scope and Method. Palo Alto: Stanford University Press. 3-15.

Lasswell, H.D. \& Lerner, D. (1951): The Policy Sciences. Recent Developments in Scope and Method. Palo Alto: Stanford University Press.

Levi-Faur, D. (Ed.). (2011). Handbook on the Politics of Regulation. Edward Elgar Publishing.

Mastenbroek, E. (2017). Guardians of EU law? Analysing roles and behaviour of Dutch legislative drafters involved in EU compliance. Journal of European Public Policy, 24(9): 1289-1307.

Meltsner, A.J. (1976) Policy analysts in the bureaucracy, Berkeley: University of California Press.

Otenyo, E.E. \& Lind, N.S. (2006). Comparative public administration: the essential readings. Amsterdam: Elsevier JAI.

North, D. (1990). Institutions, institutional change, and economic performance. Cambridge: Cambridge University Press.

Page, E.C. (2012) Policy without politicians: Bureaucratic influence in comparative perspective, Oxford: Oxford University Press. 
Page, E.C. and V. Wright (1999) Bureaucratic elites in Western European states: a comparative analysis of top officials. Oxford, Oxford University Press.

Page, E., \& Jenkins, W. I. (2005). Policy bureaucracy: Government with a cast of thousands. Oxford: Oxford University Press.

Pal, L. (2012). Frontiers of governance: The OECD and global public management reform. Houndmills: Palgrave.

Pal, L.A. and Clark, I.D. (2016). Teaching public policy: Global convergence or difference? Policy and Society, 35(4): 283-297.

Pattyn, V. (2014). Why organizations (do not) evaluate? Explaining evaluation activity through the lens of configurational comparative methods. Evaluation, 20(3), 348-367.

Pierre, J. (1995). Bureaucracy in the Modern State: An Introduction to Comparative Public Administration. Cheltenham: Edward Elgar.

Pollitt, C. (2005). Performance management in practice: A comparative study of executive agencies. Journal of Public Administration Research and Theory, 16(1), 25-44.

Pollitt, C. (2011). Not Odious but Onerous: Comparative Public Administration. Public Administration, 89(1): 114-127.

Raadschelders, J.C.N. (2011). Commentary - Between "Thick Description" and Large-N Studies: The Fragmentation of Comparative Research. Public Administration Review, 71(6): 831-833.

Raadschelders, J. C., \& Lee, K. H. (2011). Trends in the study of public administration: Empirical and qualitative observations from Public Administration Review, 2000-2009. Public Administration Review, 71(1), 19-33.

Kickert, W. J., Randma-Liiv, T., \& Savi, R. (2015). Politics of fiscal consolidation in Europe: a comparative analysis. International Review of Administrative Sciences, 81(3), 562-584.

Riggs, F.W. (1997). Modernity and Bureaucracy. Public Administration Review, 57(4): 347 353.

Siffin, W.J. (1991). The problem of development administration. In A. Farazmand (Ed.), Handbook of comparative and development administration [pp. 5-14]. New York: Marcel Dekker.

Subramaniam, V. (2000). Comparative Public Administration: From Failed Universal Theory to Raw Empiricism. A Frank Analysis and Guidelines Towards a Realistic Perspective. International Review of Administrative Sciences, 66(4): 557-572. 
Teorell, J., Dahlberg, S., Holmberg, S., Rothstein, B., Khomenko, A. \& Svensson. R. (2017). The Quality of Government Standard Dataset, version Jan17. University of Gothenburg: The Quality of Government Institute, http://www.qog.pol.gu.se doi:10.18157/QoGStdJan17

Van der Meer, F. M., Van den Berg, C. F., \& Dijkstra, G. S. (2013). Rethinking the 'Public Service Bargain': the changing (legal) position of civil servants in Europe. International Review of Administrative Sciences, 79(1), 91-109.

Van Wart, M., Hondeghem, A. \& E. Schwella (2014) Leadership and Culture: Comparative Models of Top Civil Servant Training. Basingstoke, Palgrave McMillan.

Van de Walle, S. (2006). The state of the world's bureaucracies. In: Journal of Comparative Policy Analysis, 8 (4): 439-450.

Verhoest, K., Van Thiel, S., Bouckaert, G., Lægreid, P., \& Van Thiel, S. (Eds.). (2016). Government agencies: practices and lessons from 30 countries. Springer.

Verhoest, K., \& Bouckaert, G. (2005). Machinery of government and policy capacity: The effects of specialization and coordination. Challenges to state policy capacity: Global trends and comparative perspectives, 92-111.

Verhoest, K., Vandenabeele, W., Wynen, J. \& Van de Walle, S. (2017). Challenges for largescale international comparative survey-based research in public administration.. In: Ongaro, E. \& Van Thiel.S. (eds). The Palgrave Handbook of Public Administration and Management in Europe. Houndmills: Palgrave.

Van Dooren, W., Bouckaert, G., \& Halligan, J. (2015). Performance management in the public sector. London: Routledge.

Van Wart, M.R. \& Cayer, N.J. (1990). Comparative Public Administration: Defunct, Dispersed, or Redefined? Public Administration Review, 50: 238-248.

Wilson, D. (2011). Comparative Analysis in Public Management. Public Management Review, 13(2): 293-308.

Wilson, W. (1887). The Study of Administration. Political Science Quarterly, 2(2): 197-222

Wu, X., Ramesh, M. and Howlett, M. (2017) Policy Capacity and Governance: Assessing Governmental Competences and Capabilities in Theory and Practice. Springer. DOI 10.1007/978-3-319-54675-9. 